\title{
Maskulinisasi larva ikan nila (Oreochromis niloticus) melalui penggunaan madu dengan konsentrasi berbeda
}

\author{
Masculinization of nile tilapia (Oreochromis niloticus) \\ larvae by using honey at different concentration
}

\author{
Soesanti S. Odara ${ }^{1}$, Juliaan Ch. Watung ${ }^{2}$, Hengky J. Sinjal ${ }^{2}$ \\ 1) Mahasiswa Program Studi Budidaya Perairan FPIK UNSRAT Manado \\ 2) Staf pengajar pada Program Studi Budidaya Perairan FPIK UNSRAT Manado \\ Email: hengkysinjal@gmail.com
}

\begin{abstract}
This study aimed to determine the effect of concentration of honey on masculinization of nile tilapia female. The study had four treatments, each with three replications. The experimental design used was completely randomized design (RAL). Data was analyse using Analysis Of Variance (ANOVA) followed by LSD at $5 \%$ and $1 \%$. Broodstock was soaked in $1 \mathrm{~L}$ of water with treatment A $0 \mathrm{~mL}$ (without honey), B (5 mL honey), C (10 mL honey), D (15 mL honey) for 10 hours. After soaking, fish was reared in pan for one month. The percentage of male was determine by comparing the length and width of the red blood cells under a microscope. The results showed the the use of honey had significant effect on female masculinization. The percentage of male larvae tended to increase with the increase of honey dose. The highest percentage of male was obtained in treatment D (15 ml) that was $80 \%$.
\end{abstract}

Keywords: Honey, masculinization, larvae, Oreochromis niloticus

\section{PENDAHULUAN}

Ikan nila merupakan salah satu jenis ikan air tawar yang cukup populer di Indonesia karena mempunyai nilai ekonomis penting dan merupakan komuditas unggulan. Sifat unggul dari ikan tersebut misalnya memiliki laju pertumbuhan yang cepat dan toleran pada kondisi lingkungan yang tinggi. Tetapi ikan ini juga memiliki kekurangan yaitu mudah kawin silang dan bertelur secara liar sehingga untuk mencapai ukuran konsumsisedikit sulit karena menurut Khairuman dan Amri (2008), khususnya untuk ikan nila betina setelah ukuran 200 gram akan mulai bereproduksi. Jadi energi yang dihasilkan oleh ikan nila betina tidak sepenuhnya digunakan untuk pertumbuhan melainkan untuk reproduksi dan pergerakan.

Menurut Yuliati $d k k$. (2003) sifat mudah berkembang biak mengakibatkan pertumbuhan menurun 10 - $20 \%$ per generasi yang ditandai dengan ukuran tubuh yang kecil, lambat tumbuh dan cepat matang gonad pada ukuran kecil. Pertumbuhan juga dipengaruhi oleh kualitas dan kuantitas pakan, umur dan kualitas air pemeliharaan ( Putra dkk, 2011 ). Dean (2004) menyatakan bahwa perendaman larva dalam larutan madu, maka madu akan masuk ke dalam tubuh ikan melalui insang, kulit dan gurat sisi serta melalui proses difusi. Karena madu mengandung kalium yang dapat merubah lemak menjadi prenegnelon inilah yang akan merubah estrogen menjadi progesteron. Dengan berubahnya estrogen 
menjadi progesteron, maka ikan yang tadinya menjadi betina akan diarahkan menjadi ikan jantan. Karena madu berfungsi sebagai antioksidan, diantaranya adalah chrysin, pinobaksin, vitamin C, katalase dan pinocebrin. Zat chrysin merupakan salah satu jenis flavonoid yang diakuai sebagai salah satu penghamabat enzim aromatase atau lebih dikenal sebagai aromatase inhibitor.

\section{METODE PENELITIAN}

Tujuan penelitian ini menggunakan madu dengan dosis berbeda untuk mengetahui pengaruh konsentrasi madu terhadap maskulinisasi larva ikan nila. Perlakuan madu yang dicobakan adalah sebagai berikut:
A : $0 \mathrm{~mL}$ madu dalam satu liter air
B : 5 mL madu dalam satu liter air
C : $10 \mathrm{~mL}$ madu dalam satu liter air
D : 15 mL madu dalam satu liter air

Dalam percobaan ini, setiap perlakuan memiliki tiga ulangan dan dilakukan dalam dua tahap yaitu tahap perendaman selama 10 jam dan tahap pemeliharaan selama satu bulan.

\section{Penentuan Kelamin Jantan}

Penentuan kelamin jantan dilakukan dengan membandingkan ukuran panjang dan lebar sel darah merah benih ikan di bawah mikroskop sehingga dapat diketahui persentase benih jantan (Sunarsi dan Suprata dalam Panigoro, 2001). Pengujian sel darah merah dilakukan dengan mengukur rata - rata panjang dan lebar 20 sel darah merah pada semua ikan setiap satuan percobaan. Berdasarkan pengukuran sel darah merah yang dilakukan dapat diketahui persentase benih jantan yang dihitung dengan menggunakan rumus :

Benih jantan $(\%)=$

(jumlah benih jantan/jumlah benih) x 100

\section{Sintasan Larva}

Sintasan hidup larva ditentukan pada akhir percobaan dan persentase sintasan hidup larva dari larva yang diberi perlakuan tersebut dapat dihitung dengan menggunakan rumus menurut Murtidjo (2001), adalah sebagai berikut :

$$
\operatorname{Sr}(\%)=\frac{\mathrm{Nt}}{\mathrm{No}} \mathrm{X} 100 \%
$$

Keterangan :

$\mathrm{Sr}=\operatorname{Sintasan}(\%)$

$\mathrm{Nt}=$ Jumlah larva pada akhir pengumpulan data

No = Jumlah larva pada awal pengumpulan data

\section{Pelaksanaan}

\section{a. Perendaman larva}

Untuk mendapatkan telur dilakukan perangsangan dengan ovaprim pada induk ikan nila (Orochromis niloticus), sedangkan untuk mendapatkan sperma dilakukan pembedahan pada induk jantan ikan nila, fertilisasi dilakukan dengan cara mencampurkan sperma dan telur, kemudian telur tersebut ditebarkan dalam wadah untu penetasan. Hasil penetasan dilanjutkan dengan perendaman larva, cara perendaman masing - masing loyang diisi air sebanyak satu liter air dan 20 larva ikan nila, setelah itu diberi perlakuan menggunakan madu, madu diukur dengan gelas ukur, yang dimulai dari perlakuan B (5 ml madu dalam satu liter air), sampai pada perlakuan D (15 ml madu dalam satu liter air), pada perlakuan A (tanpa madu), kemudian perendaman selama 10 jam.

b. Pemeliharaan larva

Pemeliharaan larva dilakukan dalam loyang selama satu bulan, dengan masing masing perlakuan, dipelihara pada 12 loyang yang berbeda,dengan diberi pakan dan mengontrol kualitas air.

c. Penentuan jantan dan betina

Setelah pemeliharaan satu bulan, masing - masing perlakuan diambil darahnya dengan memotong bagian ekor ikan uji dan langsung diteteskan pada kaca preparat I yang telah direndam dalam alkohol 70\% selama 1 jam. Ulasan tipis darah dibuat dengan menempelkan kaca preparat II pada tepi tetesan darah pada kaca preparat I membentuk 
sudut $45^{\circ}$. Kaca preparat II ditarik kebelakang kemudian didorong kembali ke depan, sehingga membentuk lapisan tipis. Lapisan tipis darah kemudian dikeringkan dalam suhu ruangan.Pengamatan diameter sel darah merah dilakukan dengan menggunakan mikroskop pembesaran 400 x (Prihadi dan Gustano, 1996) dan diukur dengan mikrometer okuler.

\section{HASIL DAN PEMBAHASAN}

\section{Penentuan Jenis Kelamin Jantan}

Penentuan Jenis kelamin jantan dilakukan dengan menganalisa ukuran panjang dan lebar sel dara merah. Hasil yang diperoleh dapat dilihat pada Tabel 1.

Dari hasil perhitungan data rata - rata ikan jantan tiap perlakuan menunjukan perlakuan $\mathrm{D}$ (15 ml madu dalam satu liter air) memberikan persentase tertinggi yaitu $80 \%$, kemudian menurun pada perlakuan C 63.33\% dan diikuti dengan perlakuan B 60\% serta perlakuan A 51.66. hasil analisis ragam menunjukan bahwa konsentrasi madu memberikan pengaruh nyata terhadap maskulinisasi larva ikan nila (Oerochromis niloticus). Hal ini ditujukan oleh F-hitung lebih besar dari F-tabel pada taraf 5\% (7.02>4.07), namun lebih kecil dari F-tabel pada taraf $1 \%(7.02<7.95)$. Untuk melihat perbedaan dari tiap perlakuan maka dilakukan uji lanjut BNT 5\% dan uji BNT 1\%, hasil uji BNT menunjukan perlakuan A ( kontrol) tidak berbeda nyata dengan perlakuan $\mathrm{B}(5 \mathrm{ml}$ madu dalam satu liter air) dan C (10 ml madu dalam satu liter air) sedangkan perlakuan D ( $15 \mathrm{ml}$ madu dalam satu liter air) berbeda nyata dengan perlakuan A (kontrol) perlakuan B (5 ml madu dalam satu liter air) tidak berbeda nyata dengan perlakuan C ( $10 \mathrm{ml}$ madu dalam satu liter air) namun berbeda nyata dengan perlakuan D (15 $\mathrm{ml}$ dalam satu liter air), dan perlakuan D ( $15 \mathrm{ml}$ madu dalam satu liter air) berbeda nyata dengan perlakuan $\mathrm{C}$ ( $10 \mathrm{ml}$ madu dalam satu liter air). Pada ikan perubahan kelamin individual dimungkinkan terjadi baik secara alamiah maupun rekayasa.
Dari hasil perhitungan rata - rata ikan jantan tiap perlakuan bahwa perlakuan D (15 ml madu dalam satu liter air) memberikan persentase tertinggi yaitu $80.00 \%$. Keberhasilan pengarahan jenis kelamin jantan pada ikan nila diduga terkait kadar kalium dan mineral lainnya yang terdapat dalam madu.

Menurut Marhiyanto (1999) dalam Riyanto (2001) bahwa dalam setiap 100 gram madu terkandung 205-1676 ppm Kalium, 4951 ppm Kalsium, 19-35 ppm Magnesium dan 18 ppm Natrium. Syaifuddin, (2004) berpendapat tingginya kandungan kalium yang diberikan pada perubahan kolesterol yang terdapat dalam semua jaringan tubuh anak menjadi pregnenolon. Pregnenolon merupakan sumber dari biosintetis hormone - hormon steroid oleh kelenjar adrenal, steroid tersebut berpengaruh terhadap pembentukkan testosteron. Hormon testosteron akan mempengaruhi perkembangan dari genital jantan, karakteristik seks sekunder jantan dan spermatogenesis (Syaifuddin, 2004). Kemampuan madu dalam meningkatkan rasio jenis kelamin disebabkan olehkandungan mineralnya (natrium, kalsium, magnesium dan kalium) yang bersifat reaksi alkalis pada cairan ekstraseluler (Winarno, 1995 dalam Riyanto, 2001). Selain itu jenis kelamin (seks determinasi) ditentukan oleh gen dan faktor perubahan lingkungan sekitarnya seperti temperatur dan lainnya (Shapiro dalam Redding dan Pation, 1993). Hasil yang diperoleh D $(15 \mathrm{ml} / \mathrm{l})$ yaitu $80,00 \%$ jika dibandingkan dengan hasil penelitian Syaifuddin (2004), perlakuan dengan madu dengan dosis $200 \mathrm{ml} / \mathrm{kg}$ pakan terhadap besarnya rasio jenis kelamin jantan ikan nila GIFT (Oreochromis niloticus) yang diberikan secara oral mampu memberi pengaruh yang nyata sebesar 93,33\%, jika dilihat dosis madu yang diberikan, lebih tinggi dosis madu maka hasil presentase jantan juga tinggi, begitu juga sebaliknya jika dosis madu yang diberikan lebih rendah maka hasil presentase jantan juga ikut rendah. 
Tabel 1. Hasil ikan jantan dengan perlakuan madu.

\begin{tabular}{|c|c|c|c|c|c|}
\hline \multirow{2}{*}{ Ulangan } & \multicolumn{4}{|c|}{ Perlakuan } & Total \\
\hline & $\mathrm{A}(\mathbf{0} \mathrm{ml})$ & B (5 ml) & $\mathrm{C}(10 \mathrm{ml})$ & D (15 ml) & \\
\hline 1 & 50 & 70 & 70 & 90 & \\
\hline 2 & 55 & 60 & 60 & 80 & \\
\hline 3 & 50 & 50 & 60 & 70 & \\
\hline$\sum$ & 155 & 180 & 190 & 240 & \\
\hline Rataan \% & 51.66 & 60 & 63.33 & 80 & 756 \\
\hline
\end{tabular}

Keterangan :

Perlakuan A : Dosis larutan madu $0 \mathrm{ml}$

Perlakuan B : Dosis larutan madu $5 \mathrm{ml}$

Perlakuan C : Dosis larutan madu $10 \mathrm{ml}$

Perlakuan D : Dosis larutan madu $15 \mathrm{ml}$

\section{Sintasan larva ikan nila}

Hasi persentase sintasan larva ikan nila (Oreochromis niloticus) dapat dilihat pada Tabel 2. Hasil persentase rata - rata sintasan larva ikan uji tiap perlakuan menunjukan bahwa perlakuan $\mathrm{D}(15 \mathrm{ml}$ madu dalam satu liter air ) memberikan presentase tertinggi yaitu 86,66. Berdasarkan analisis ragam menunjukan nilai F-hitung (1.03) lebih kecil dari F-tabel 5\% dan 1\%, ini berarti perbedaan perlakuan memberikan pengaruh yang tidak nyata terhadap sintasan larva ikan nila yang diujicobakan. Hasil persentase sintasan larva yang diperoleh selama pemeliharaan menunjukkan persentase sintasan yang tidak nyata. Ini berarti madu tidak mampu memberikan sintasan hidup larva. Selama penelitian kualitas air dalam perlakuan tidak begitu banyak mengalami perubahan. Perubahan kualitas air terjadi pada saat perlakuan dilakuakan, perubahan yang signifikan terjadi pada kualitas air dengan parameter DO (Dissolved Oxygen).

Kadar DO merupakan kualitas air yang banyak mengalami perubahan diawal dan akhir perlakaun. Awal perlakuan menunjukan kadar DO berkisar 5,35 mg/l sampai 8,52 mg/l, sedangkan akhir perlakuan 4,26 mg/l sampai 7,33 mg/l. Penurunan kadar DO terjadi karena kadar air madu yang tinggi dapat merangsang terjadinya proses fermentasi madu yang disebabkan oleh aktivitas jamur yang terdapat dalam madu Almayanty (1998) dalam Sarida (2010). Semakin rendah kadar airnya, maka peluang fermentasi pada madu semakin kecil dan lambat. Hal tersebut diakibatkan adanya kandungan dalam madu yang dapat mengahambat pertumbuhan jamur.

Kandungan $\mathrm{pH}$ yang ideal bagi produktivitas pada perairan adalah 5,5 sampai 6,5 sedangkan kisaran $\mathrm{pH}$ yang baik untuk pemeliharaan ikan adalah 7 sampai 8,5 Effendy (2003) dalam sarida (2010). $\mathrm{pH}$ dalam perlakuan berada pada kisaran 6 sampai 7. Penurunan $\mathrm{pH}$ mengakibatkan metabolism ikan menjadi terganggu. Perubahan nilai $\mathrm{pH}$ juga berpengaruh pada kadar $\mathrm{CO}_{2}$ dalam air, semakin tinggi nilai $\mathrm{pH}$ semakin rendah kadar $\mathrm{CO}_{2}$ bebas. Sebaliknya semakin rendah nilai $\mathrm{pH}$ maka semakin tinggi kadar $\mathrm{CO}_{2}$ bebas.

Suhu merupakan faktor ekstenal yang dapat berpengaruh terhadap fenotip betina menjadi jantan pada ikan yang memiliki genotip betina. Suhu selain berpengaruh perubahan fenotip juga berpengaruh terhadap kecepatan metabolisme ikan. 
Tabel 2. Hasil persentase Sintasan larva ikan nila (Oreochromis niloticus)

\begin{tabular}{|c|c|c|c|c|c|}
\hline \multirow[t]{2}{*}{ Ulangan } & \multicolumn{4}{|c|}{ Perlakuan } & Total \\
\hline & A (0 ml) & B (5 ml) & $\mathrm{C}(10 \mathrm{ml})$ & D (15ml) & \\
\hline 1 & 75 & 95 & 80 & 95 & \\
\hline 2 & 80 & 65 & 70 & 80 & \\
\hline 3 & 85 & 70 & 70 & 85 & \\
\hline$\sum$ & 240 & 230 & 220 & 260 & \\
\hline Rataan (\%) & 80,00 & 76.66 & 73.33 & 86.66 & 950 \\
\hline
\end{tabular}

Keterangan :

Perlakuan A : Dosis larutan madu $0 \mathrm{ml}$

Perlakuan B : Dosis larutan madu $5 \mathrm{ml}$

Perlakuan C : Dosis larutan madu $10 \mathrm{ml}$

Perlakuan D : Dosis larutan madu $15 \mathrm{ml}$

Laju metabolisme dapat dipercepat dua kali dengan peningkatan suhu sebesar 10 ${ }^{\circ} \mathrm{C}$ Effendi (2003) dalam sarida (2010). Suhu dalam penelitian berada pada kisaran $26{ }^{\circ} \mathrm{C}$ sampai $27{ }^{\circ} \mathrm{C}$.Kisaran suhu dalam penelitian tersebut, diduga tidak memberikan pengaruh terhadap pengarahan kelamin jantan, sehingga pengaruh pengarahan kelamin jantan hanya disebabkan oleh perlakuan. Hal tersebut menunjukan bahwa suhu dalam penelitian masih berada pada kisaran ikan nila dapat bertahan hidup.

\section{KESIMPULAN}

1. Penambahan madu pada larva ikan nila (Oreochromis niloticus) berpengaruh nyata terhadap persentase jantan ikan nila, tapi tidak berpengaruh pada sintasan larva.

2. Perlakuan D memiliki tingkat persentase jantan tertinggi dengan yaitu $80 \%$.

3. Kosentrasi larutan madu tidak memberikan pengaruh nyata terhadap sintasan hidup larva ikan nila (Oreochromis niloticus).

\section{DAFTAR PUSTAKA}

Dean W. 2004. Chrysin: Is It An Effective Aromatase Inhibitor. Vitamin Research News.Vol 18, No. 4.http://www.vrp.com [9 Mei 2011].

Khairuman, Amri K. 2008.Buku Pintar Budidaya 15 Ikan Komsumsi Agromedia Pustaka. Jakarta.

Murtidjo BA. 2001. Beberapa Metode Pembenihan Ikan Air Tawar. Penerbit Kanisius, Yogyakarta.

Panigoro N. 2001. Triploidisasi Ikan Mas (Cyprinus carpio L) Dengan Kejutan Suhu Yang Berbeda. Fakultas Perikanan dan Ilmu Kelautan UNSRAT Manado (Skripsi).

Putra I, Setiyanto DD, Wahyjuningrum D. 2011. Pertumbuhan dan Kelangsungan Hidup Ikan Nila (Oreochromis niloticus DalamSistem Reproduksi. Jurnal Perikanan dan Kelautan 16,1 : 56-63.

Prihadi TH, Gustiano R. 1996. Poliploidi Buatan pada Ikan Mas (Cyprinus carpio L) dengan Kejutan Panas. Prosiding/Puslibangkan/No. $\quad 40$ : 133- 145 
Redding MJ, Patino R. 1993. Reproductive Physiology. P: 503-526. In: D. H. Evans (Ed.), The Physiology of Fishes. CRC Press Inc.

Riyanto. 2001. Pengaruh Pemberian Suplement Madu Pada Induk Mencit Terhadap Rasio Jenis Kelamin Anaknya. Berita Biologi. 5 (4).

Sarida M. 2010. Penggunaan Madu dalam Produksi Ikan Guppy Jantan (Poecillia reticulata). Naska publikasi; Fakultas Pertanian Perikanan Universitas Lampung.
Syaifuddin A. 2004.Pengaruh pemberian suplement madu pada pakan larva Ikan Nila GIFT (Oreochromis niloticus) terhadap rasio jenis kelaminnya.Skripsi. Universitas Brawijaya. Fakultas Perikanan. Malang.

Yuliati P, Kadarini T, Rusmaedi, Subandiyah S. 2003. Pengaruh Padat Penebaran Terhadap Pertumbuhan dan Sintasan Dederan Ikan Nila Gift (Oreochromis niloticus) Di Kolam. Jurnal Iktiologi Indonesia, vol. 3, no 2. 